\title{
PERBEDAAN KEMANDIRIAN BELAJAR SISWA PADA MASA PANDEMI DI SMAN 1 LEMBAH MELINTANG DAN SMAN 1 LEMBAH GUMANTI
}

\author{
Ambiyar ${ }^{1}$, Ishak Aziz ${ }^{2}$, Melisa $^{3}$ \\ ${ }^{1,2}$ Universitas Negeri Padang \\ ${ }^{3}$ STKIP PGRI Sumatera Barat \\ ambiyar@ft.unp.ac.id
}

\begin{abstract}
The limited interaction between teachers and students in online learning, especially in mathematics, requires students to be independent in learning. The importance of independent learning during the Covid 19 pandemic is the background of this research. This study aims to determine differences in student learning independence during the pandemic in mathematics learning in SMAN 1 Lembah Melintang and SMAN 1 Lembah Gumanti. This research was conducted on August 31, 2020, the odd semester of the 2020/202 school year, during the pandemic. The sampling technique used purposive sampling. This research is an experimental research with the type of research is a quasi-experimental, because the class used has been formed before. The quasi-experimental research method used the two-way test by calculating the $t$ test. Through the calculation of the $t$ test, it is found that $\mathrm{t}_{\text {count }}<\mathrm{t}_{\text {table }}$ which means that $\mathrm{H}_{0}$ is accepted. So it can be concluded that there is no difference in learning independence during the pandemic at SMAN 1 Lembah Melintang and SMAN 1 Lembah Gumanti.
\end{abstract}

Keywords: Differences, Learning Independence, Pandemic

\begin{abstract}
Abstrak
Terbatasnya interaksi guru dan siswa dalam pembelajaran daring khususnya pada mata pelajaran matematika, mengharuskan siswa untuk memiliki kemandirian dalam belajar. Pentingnya kemandirian belajar pada masa pandemi covid 19 menjadi latar belakang pada penelitian ini. Penelitian ini bertujuan untuk mengetahui perbedaan kemandirian belajar siswa pada masa pandemi dalam pembelajaran matematika di kelas XI IPA 2 SMAN 1 Lembah Melintang dan di kelas XI MIPA IV SMAN 1 Lembah Gumanti. Penelitian ini dilaksanakan pada tanggal 31 Agustus 2020, semester ganjil tahun pelajaran 2020/202, pada masa pandemi. Teknik pengambilan sampel menggunakan purposive sampling. Penelitian ini merupakan penelitian eksperimen dengan jenis penelitiannya adalah quasi eksperiment (eksperimen semu), sebab kelas yang digunakan telah terbentuk sebelumnya. Metode penelitian quasi ekperimen menggunakan uji dua pihak dengan melakukan perhitungan uji t. Melalui perhitungan uji t diperoleh bahwa $t_{\text {hitung }}<t_{\text {tabel }}$ yang berarti terjadi penerimaan $\mathrm{H}_{0}$. Jadi dapat disimpulkan bahwa tidak terdapat perbedaan kemandirian belajar pada masa pandemi di SMAN 1 Lembah Melintang dan SMAN 1 Lembah Gumanti.
\end{abstract}

Kata kunci: Perbedaan, Kemandirian Belajar, Masa Pandemi

\section{PENDAHULUAN}

Pandemi covid-19 telah mengganggu proses pembelajaran secara konvensional. Melalui Kementerian Pendidikan dan Kebudayaan, Pemerintah telah melarang perguruan tinggi dan sekolah untuk melaksanakan perkuliahan tatap muka (konvensional) dan memerintahkan untuk menyelenggarakan perkuliahan atau pembelajaran secara daring (Surat Edaran Kemendikbud Dikti No. 1 tahun 2020). Pembelajaran merupakan proses aktif yang dihasilkan melalui keterlibatan aktif individu dalam merefleksikan pengalaman dan tindakan yang iapraktikkan dilingkungan tertentu 
(Wulandari, 2016). Menurut (Ali Sadikin, 2019) pembelajaran daring merupakan pembelajaran yang menggunakan jaringan internet dengan aksesibilitas, konektivitas, fleksibilitas, dan kemampuan untuk memunculkan berbagai jenis interaksi pembelajaran. Melalui pembelajaran daring, siswa diharapkan dapat mandiri dalam belajar. Kemandirian belajar siswa dalam pembelajaran daring terlihat dari kemampuan siswa dalam mengatur waktu dan memanfaatkan berbagai sumber belajar. Artinya, untuk mencapai suatu pemahaman terhadap materi, siswa tidak bergantung pada materi yang diberikan guru. Kemandirian belajar merupakan usaha melakukan aktivitas belajar dengan cara mandiri atas dasar motivasinya sendiri untuk menguasai suatu materi tertentu sehingga bisa dipakai untuk memecahkan masalah yang sedang dihadapi, dengan demikian siswa yang mandiri harus proaktif serta tidak tergantung pada guru (Asep Sukenda Egok, 2016). Ini berarti, dalam proses pembelajaran, siswa dituntut untuk mandiri dalam mempelajari semua mata pelajaran termasuk matematika. Matematika merupakan salah satu mata pelajaran yang sangat penting dalam perkembangan pengetahuan dan teknologi (Ermayeni et al., 2020). (Karlimah et al., 2012) berpendapat bahwa matematika dianggap sebagai kemampuan kunci yang harus dimiliki siswa untuk menunjang penguasaan sebagian besar bidang-bidang keilmuan lainnya.

Observasi dilakukan pada tanggal 06-11 Januari 2020 (sebelum pandemic) di kelas X IPA 2 SMAN 1 Lembah Melintang Kabupaten Pasaman Barat dan kelas X MIPA SMAN 1 Lembah Gumanti dalam pembelajaran matematika. Berdasarkan hasil observasi ditemukan bahwa siswa kurang memiliki kemandirian dalam belajar. Kurangnya kemandirian siswa dalam belajar disebabkan karena guru masih sering menjadi pusat dalam proses pembelajaran dan mendominasi aktivitas mengajar menyebabkan siswa merasa ketergantungan dan kurang aktif dalam pembelajaran di kelas. Beberapa siswa ditemukan tidak mampu menyelesaikan tugasnya secara mandiri. (Ansori \& Herdiman, 2019) menyatakan siswa harus memiliki sikap mandiri dalam segala bidang khususnya belajar atau menyelesaikan tugas-tugas sekolah. Permasalahan selanjutnya, rendahnya minat dan kualitas belajar siswa terhadap mata pelajaran matematika, mengakibatkan rendahnya kemandirian belajar sehingga menghambat berkembangnya kemampuan berfikir matematis.

Menurut (Nurhayati, 2017), dalam visi pendidikan matematika, individu yang belajar matematika dituntut memiliki kemandirian belajar yang tinggi, yang kemudian akan menghasilkan kemampuan berpikir matematik yang diharapkan. Menurut (Latif \& Akib, 2016) kemampuan berfikir matematik dapat diklasifikasikan dalam lima kompetensi utama yaitu pemahaman matematis (mathematical understanding), pemecahan masalah (mathematical problem solving), komunikasi matematis (mathematical communication), koneksi matematis (mathematical connection) dan penalaran matematis (mathematical reasoning). Kemampuan berfikir matematis, khususnya pemecahan masalah mendorong siswa untuk belajar mandiri. Kemampuan pemecahan masalah matematis merupakan suatu kemampuan matematis yang sangat penting karena menempati sebagai tujuan umum dan utama dalam pembelajaran matematika (Darma et al., 2016). (Mayasari, 2019) menyatakan terdapat hubungan positif antara kemandirian dan kemampuan pemecahan masalah. Hal 
ini sejalan dengan pendapat (Risnanosanti, 2013), yang mengatakan bahwa cara belajar mahasiswa mandiri mampu menunjang kemampuan pemecahan masalah matematis mahasiswa.

Wawancara yang dilakukan dengan guru memperoleh informasi bahwa siswa tidak menyukai tantangan yang diberikan oleh guru. Guru menyampaikan bahwa ketika siswa diberikan soal pemecahan masalah, siswa mengeluh dan hanya beberapa orang siswa saja yang mau mencoba mengerjakannya. Dalam mengerjakan soal pemecahan masalah berbentuk soal cerita, beberapa beberapa siswa kesulitan dalam memahami masalah yang disajikan pada soal. Hasil wawancara yang dilakukan terhadap siswa, didapat informasi bahwa beberapa siswa kesulitan dalam memahami masalah dan membuat model matematika. Siswa membutuhkan waktu yang cukup lama dalam memahami masalah yang ada pada soal cerita. Siswa menyerah dan tidak mau mencoba. Siswa cenderung bertanya dan meniru jawaban dari temannya.

Berdasarkan uraian di atas, tampak bahwa kemandirian sangat penting dimiliki oleh siswa, baik dalam pembelajaran luring maupun daring. Hal ini sejalan dengan pendapat (Amalia et al., 2018) bahwa "kemandirian belajar siswa menuntut mereka untuk aktif baik sebelum dan sesudah proses pembelajaran berlangsung, sehingga siswa yang menerapkan belajar mandiri akan mampu memecahkan masalahnya sendiri”. Kemandirian belajar siswa adalah sejauh mana dalam proses pembelajaran siswa dapat ikut menentukan tujuan, materi dan pengalaman belajar, serta evaluasi pembelajaran (Mulyono, 2017).

Pada penelitian ini, akan dilihat bagaimana kemandirian siswa dalam pembelajaran matematika, khususnya melihat indicator-indikator kemandirian yang muncul ketika siswa mengerjakan soal-soal pemecahan masalah. Kemandirian yang dilihat pada penelitian ini adalah kemandirian dari siswa yang berasal dari dua sekolah yang berbeda, yaitu SMAN 1 Lembah Melintang dan SMAN 1 Lembah Gumanti. Indikator kemandirian yang digunakan pada penelitian ini merujuk pada indicator kemandirian Saepullah. Menurut Saepullah dalam (Hendriana dkk, 2017), indikator kemandirian belajar ada delapan poin antara lain sebagai berikut: (1) Inisiatif belajar; (2) Mendiagnosa kebutuhan belajar; (3) Menetapkan tujuan dan target belajar; (4) Memandang kesulitan sebagai tantangan; (5) Memanfaatkan dan mencari sumber yang relevan; (6) Memilih dan menerapkan strategi belajar; (7) Mengevaluasi proses dan hasil belajar; dan (8) Self efficacy (konsep diri).

Berdasarkan uraian permasalahan di atas, maka peneliti tertarik untuk melihat perbedaan kemandirian belajar siswa pada masa pandemi dalam pembelajaran matematika di kelas XI IPA 2 SMAN 1 Lembah Melintang dan di kelas XI MIPA IV SMAN 1 Lembah Gumanti. sewaktu siswa mengejakan soal pemecahan masalah melalui pembelajaran daring.

\section{METODE}

Penelitian ini merupakan penelitian eksperimen dengan jenis penelitian quasi eksperiment (eksperimen semu), sebab kelas yang digunakan telah terbentuk sebelumnya. Metode penelitian quasi ekperimen diterapkan dengan desain Nonequivalent Control Group Design. Desain ini hampir sama 
Perbedaan Kemandirian Belajar Siswa Pada Masa Pandemi Di Sman 1 Lembah Melintang dan SMAN 1 Lembah

dengan pretest-posttest control group design, hanya pada desain ini kelompok sampel tidak dipilih secara random dan tidak mengadakan pretest. Uji hipotesis menggunakan uji t dua arah untuk mengetahui perbedaan kemandirian belajar siswa pada masa pandemi di SMAN 1 Lembah Melintang dan SMAN 1 Lembah Gumanti di masa pandemi covid 19. Penelitian ini dilaksanakan pada tanggal 31 Agustus 2020 di SMAN 1 Lembah Melintang dan 02 September 2020 di SMAN 1 Lembah Gumanti pada Semester Ganjil tahun pelajaran 2020/2021, di masa pandemi. Variabel bebas pada penelitian ini adalah pembelajaran daring, dan variabel terikat adalah kemandirian belajar. Subjek penelitian dipilih secara purposive sampling. Subjek penelitian adalah kelas XI IPA 2 SMAN 1 Lembah Melintang dan kelas XI MIPA IV SMAN 1 Lembah Gumanti Menurut Sugiono dalam Bella (2019) "purposive sampling adalah teknik penentuan sampel dengan pertimbangan tertentu". Berdasarkan pertimbangan yang dilakukan dalam pemilihan subjek dan saran guru bidang studi, subjek pada penelitian ini adalah siswa kelas XI IPA 2 di SMAN 1 Lembah Melintang dan siswa kelas XI MIPA IV di SMAN 1 Lembah Gumanti.

Instrumen yang digunakan adalah angket kemandirian. Penelitian dilakukan menggunakan google form. Angket kemandirian belajar dimasukkan kedalam google form lalu diisi oleh siswa dengan terlebih dahulu diberikan link melalui whatsapp group dengan tampilan sebagai berikut.

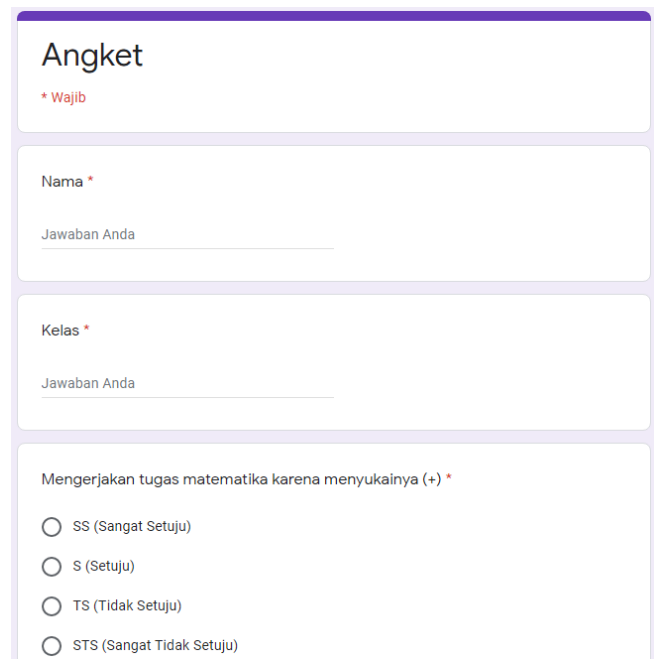

Gambar1. Tampilan Google Form untuk Angket

Angket yang digunakan pada penelitian ini adalah angket baku kemandirian belajar menurut (A Saefullah, P Siahaan, 2013) dalam (Asmar \& Delyana, 2020). Angket kemandirian belajar ini telah disusun berdasarkan indikator-indikator kemandirian belajar, dan ada beberapa pernyataan yang harus disesuaikan dengan kondisi dan situasi pembelajaran secara daring. Pernyataan terdiri dari pernyataan positif dan negatif. Angket yang digunakan adalah angket baku yang bersifat tertutup. Alur pelaksanaan penelitian adalah sebagai berikut. 


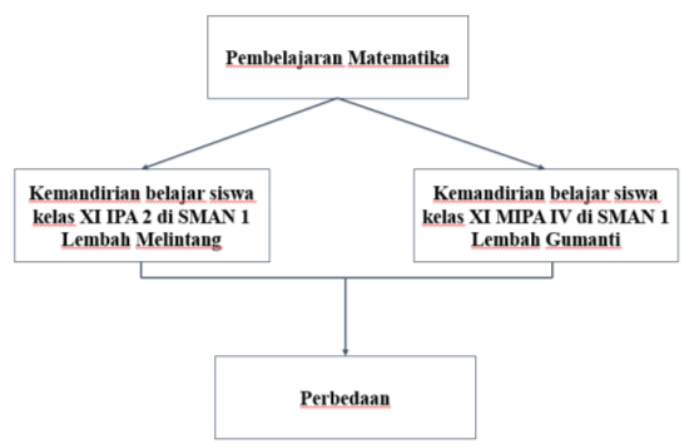

Gambar 2. Alur Pelaksanaan Penelitian

Teknik analisis data adalah analisis skor angket kemandirian belajar yang dilakukan dengan menentukan jumlah skor yang diperoleh masing-masing siswa terlebih dahulu. Jumlah skor yang diperoleh kemudian dibagi dengan jumlah skor maksimum angket dan dikali dengan $100 \%$ untuk mendapatkan persentase skor kemandirian belajar dapat dirumuskan :

$$
\text { Skor }=\frac{\text { skor yang diperoleh siswa }}{\text { skor maksimum }} \times 100 \%
$$

Persentase skor yang diperoleh diinterpretasikan berdasarkan kriteria skor angket kemandirian belajar yang terdapat pada Tabel 1, di bawah ini:

\section{Tabel 1.}

Kriteria Penilaian Kemandirian Belajar Siswa

\begin{tabular}{|c|c|}
\hline Kriteria Pengelompokan & Kategori \\
\hline $0 \leq S \leq 25$ & Sangat Lemah \\
\hline $25<S \leq 50$ & Lemah \\
\hline $50<S \leq 75$ & Kuat \\
\hline $75<S \leq 100$ & Sangat Kuat \\
\hline
\end{tabular}

Sumber: Modifikasi dari (Ridwan: 2010: 89)

Setelah diperolah skor kemandirian belajar siswa maka selanjutnya diakukan uji-t untuk menentukan adanya perbedaan kemandirian belajar pada masa pandemi di kelas XI IPA 2 SMAN 1 Lembah Melintang dan XI MIPA IV SMAN 1 Lembah Gumanti. Adapun rumus yang digunakan pada uji-t adalah sebagai berikut, menurut Sugiyono dalam (Ayu Kustiani R, Dewi Novianti, Dhani Fitri Yanthi, 2007):

Keterangan:

$$
t=\frac{\left(\bar{x}_{1}-\bar{x}_{2}\right)-d_{0}}{\sqrt{\frac{s_{1}{ }^{2}}{n_{1}}+\frac{s_{2}{ }^{2}}{n_{2}}}}
$$

$x_{1}$ :SMAN 1 Lembah Melintang

$x_{2}:$ SMAN 1 Lembah Gumanti

$\bar{x}_{1}:$ rata - rata skor $x_{1}$

$\bar{x}_{2}:$ rata - rata skor $x_{2}$ 
Perbedaan Kemandirian Belajar Siswa Pada Masa Pandemi Di Sman 1 Lembah Melintang dan SMAN 1 Lembah

$d_{0}=0$

$s_{1}=$ simpangan baku $x_{1}$

$s_{2}=$ simpangan baku $x_{2}$

$n_{1}$ : Jumlah siswa $x_{1}$

$n_{2}:$ Jumlah siswa $x_{2}$

Pengujian hipotesis pada skor angket kemandirian belajar menggunakan uji dua pihak perhitungannnya dengan menggunakan uji t. Adapun perumusan hipotesisnya adalah sebagai berikut, $\mathrm{H}_{0}$ : Tidak terdapat perbedaan kemandirian belajar siswa di SMAN 1 Lembah Melintang dan SMAN 1 Lembah Gumanti pada masa pandemi

$\mathrm{H}_{1}$ : Terdapat perbedaan antara kemandirian belajar siswa di SMAN 1 Lembah Melintang dan SMAN 1 Lembah Gumanti

\section{HASIL}

Kemadirian belajar siswa di SMAN 1 Lembah Melintang dan SMAN 1 Lembah Gumanti dilihat sewaktu siswa mengerjakan soal pemecahan masalah matematika secara mandiri. Kemandirian dapat terlihat melalui aktivitas yang didorong oleh kompetensi pemecahan masalah (Prisha Bahri et al., 2018). Siswa yang memiliki kemandirian belajar yang tinggi akan berusaha menyeleseaikan latihan atau tugas yang diberikan oleh guru dengan kemampuan yang dimiliknya, sebaliknya siswa yang memliki kemandirian belajar yang rendah akan tergantung pada orang lain (Assagaf \& Ambon, 2017). Pemaparan tentang kemandirian belajar pada kedua sekolah tersebut adalah sebagai berikut.

\section{Hasil Penelitian Penelitian di SMAN 1 Lembah Melintang}

Kemandirian siswa dalam proses pembelajaran dapat dilihat dari hasil angket kemandirian belajar yang diisi oleh responden dengan jumlah siswa sebanyak 30 orang. Adapun persentase kemandirian belajar siswa per indikator dapat dilihat pada Tabel 2.

\section{Tabel 2.}

Persentase Kemandirian Belajar Siswa

\begin{tabular}{|c|l|c|}
\hline & \multicolumn{1}{|c|}{ Indikator } & $\begin{array}{c}\text { Skor Perindikator } \\
(\%)\end{array}$ \\
\hline 1. & Inisiatif dan motivasi belajar intrinsik & 69,17 \\
\hline 2. & Mendiagnosa kebutuhan belajar & 66,11 \\
\hline 3. & Menetapkan tujuan/target belajar & 74,44 \\
\hline 4. & Memilih, menetapkan strategi belajar & 73,33 \\
\hline 5. & Memonitor, mengatur, dan mengontrol belajar & 68.06 \\
\hline 6. & Memandang kesulitan sebagai tantangan & 68,75 \\
\hline 7. & Memanfaatkan dan mencari sumber yang relevan & 69,17 \\
\hline 8. & Mengevaluasi proses dan hasil belajar & 74,17 \\
\hline 9. & Self Efficacy/konsep diri/kemampuan diri & 67,29 \\
\hline
\end{tabular}


Pada tabel 2 dapat dilihat bahwa persentase skor kemandirian belajar siswa per indikator berada di antara $65 \%$ dan $75 \%$. Hal ini dapat diartikan bahwa kemandirian belajar siswa berada pada kategori kuat. Berdasarkan Tabel 5 juga dapat diambil kesimpulan bahwa indikator kemandirian belajar siswa yang paling menonjol adalah menetapkan tujuan/target belajar yaitu dengan persentase $74,44 \%$. Sedangkan indikator paling rendah yang dipilih oleh siswa yaitu mendiagnosa kebutuhan belajar dengan persentase 66,11\%. Perhatikan Gambar 1 untuk melihat rentangan indikator kemandirian belajar siswa melalui diagram.

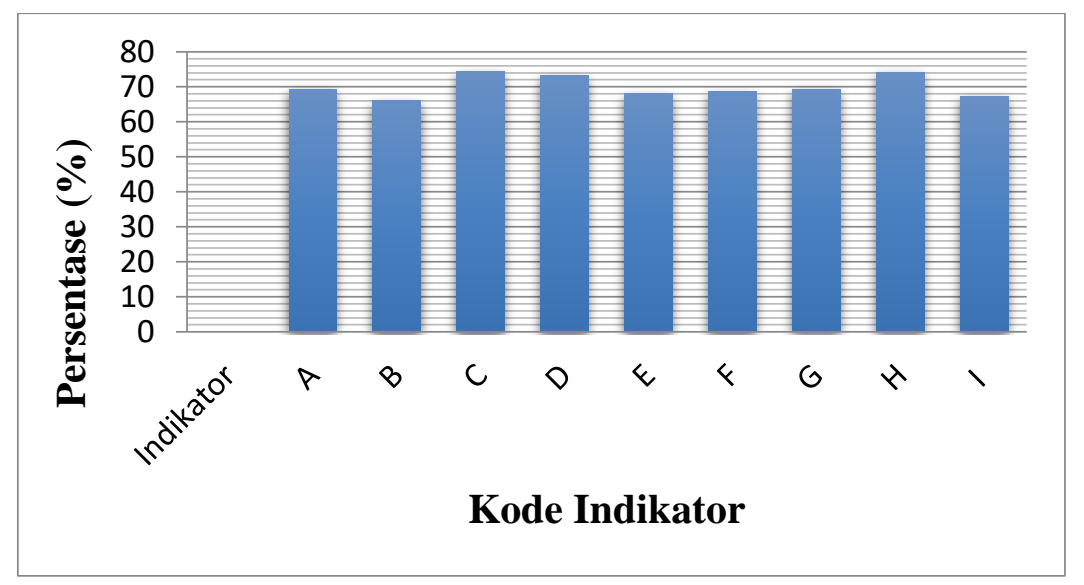

Gambar 1. Diagram Persentase Kemandirian Belajar Siswa di SMAN 1 Lembah Melintang

\section{Keterangan Diagram :}

A = Inisiatif dan motivasi belajar intrinsik

$\mathrm{B}=$ Mendiagnosa kebutuhan belajar

$\mathrm{C}=$ Menetapkan tujuan/target belajar

$\mathrm{D}=$ Memilih, menetapkan strategi belajar

$\mathrm{E}=$ Memonitor, mengatur, dan mengontrol belajar

$\mathrm{F}=$ Memandang kesulitan sebagai tantangan

$\mathrm{G}=$ Memanfaatkan dan mencari sumber yang relevan

$\mathrm{H}=$ Mengevaluasi proses dan hasil belajar

$\mathrm{I}=$ Self Efficacy/konsep diri/kemampuan diri

Melalui Gambar 1 dapat dilihat bahwa tingkat kemandirian belajar siswa perindikator memiliki selisih yang kecil. Rentangan kemandirian belajar berada pada $65<x<75$. Hal ini dapat disimpulkan bahwa setiap indikator kemandirian belajar memiliki tingkatan yang hampir sama pada pilihan siswa.

\section{Hasil Penelitian di SMAN 1 Lembah Gumanti}

Kemandirian siswa dapat dilihat dari angket yang dibagikan pada subjek penelitian dengan jumlah responden 31 siswa. Tingkat kemandirian belajar dapat dilihat dari persentase perindikator yang disajikan pada Tabel 3. 
Perbedaan Kemandirian Belajar Siswa Pada Masa Pandemi Di Sman 1 Lembah Melintang dan SMAN 1 Lembah Gumanti, Ambiyar, Ishak Aziz, Melisa

Tabel 3. Persentase Kemandirian Belajar Perindikator

\begin{tabular}{|c|l|c|}
\hline NO & \multicolumn{1}{|c|}{ Indikator } & $\begin{array}{c}\text { Skor (\%) } \\
\text { perindikator }\end{array}$ \\
\hline 1 & Inisiatif dan motivasi belajar intrinsic & 72,04 \\
\hline 2 & Mendiagnosa kebutuhan belajar & 73,12 \\
\hline 3 & Menetapkan target dan tujuan belajar & 73,66 \\
\hline 4 & Memilih, menetapkan strategi belajar & 70,56 \\
\hline 5 & Memonitor, mengatur, dan mengontrol belajar & 69,09 \\
\hline 6 & Memandang kesulitan sebagai tantangan & 67,34 \\
\hline 7 & Memanfaatkan dan mencari sumber yang relevan & 68,55 \\
\hline 8 & Mengevaluasi proses dan hasil belajar & 75,00 \\
\hline 9. & Sel-Efficacy (konsep diri) & 67,54 \\
\hline
\end{tabular}

Berdasarkan Tabel 3 terlihat bahwa persentase kemandirian belajar per indikator berada antara 67\% sampai $75 \%$ maka kemadirian belajar siswa termasuk kuat. Indikator kemandirian belajar yang paling rendah pada subjek penelitian adalah memandang kesulitan sebagai tantangan sedangkan indikator tertinggi yang dipilih oleh siswa adalah mengevaluasi proses dan hasil belajar.

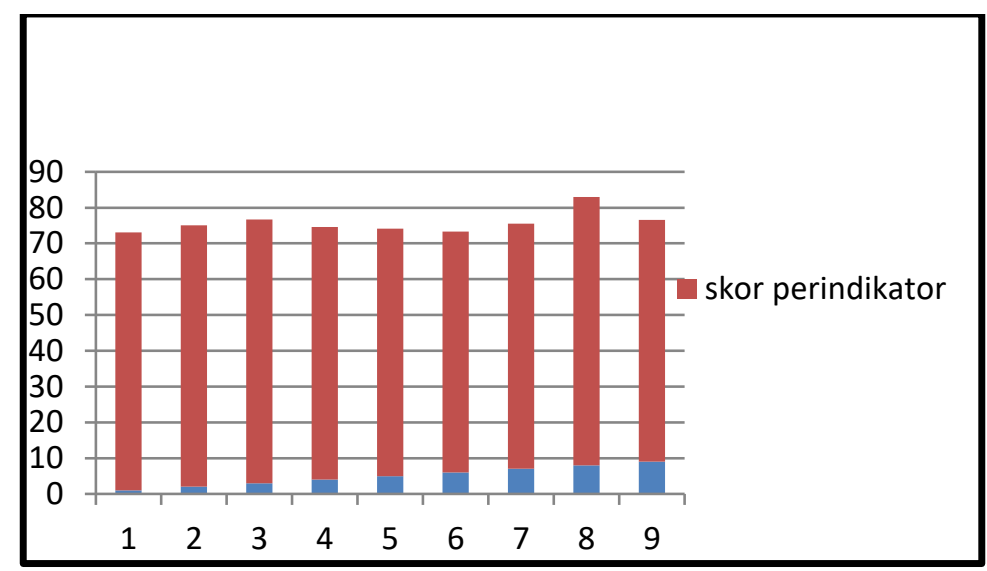

Gambar 2. Persentase Skor Angket Kemandirian Belajar di SMAN 1 Lembah Gumanti

\section{Keterangan Diagram :}

$1=$ Inisiatif dan motivasi belajar intrinsik

$2=$ Mendiagnosa kebutuhan belajar

$3=$ Menetapkan tujuan/target belajar

$4=$ Memilih, menetapkan strategi belajar

$5=$ Memonitor, mengatur, dan mengontrol belajar

$6=$ Memandang kesulitan sebagai tantangan

$7=$ Memanfaatkan dan mencari sumber yang relevan

$8=$ Mengevaluasi proses dan hasil belajar

$9=$ Self Efficacy/konsep diri/kemampuan diri 
Melalui Gambar 2 di atas dapat dilihat bahwa tingkat kemandirian belajar siswa perindikator memiliki selisih yang kecil. Rentangan kemandirian belajar berada pada $67<x<75$. Hal ini dapat disimpulkan bahwa setiap indikator kemandirian belajar memiliki tingkatan yang hampir sama pada pilihan siswa.

Setelah dilakukan perhitungan, diperoleh $\mathrm{t}_{\text {hitung }}=-0,358$ dan $\mathrm{t}_{\text {tabel }}=1,701$ pada taraf signifikan $5 \%$. Hal ini berarti $t_{\text {hitung }}<t_{\text {tabel }}$ atau dengan kata lain $t_{\text {hitung }}$ berada di daerah penerimaan $\mathrm{H}_{0}$. Dengan demikian dapat diambil kesimpulan bahwa tidak terdapat perbedaan antara kemandirian belajar siswa di SMAN 1 Lembah Melintang dan SMAN 1 Lembah Gumanti pada masa pandemi. Hal ini dapat terjadi karena adanya kesamaan karakteristik dan gaya belajar siswa.

Penelitian ini dilakukan untuk mengetahui perbedaan kemandirian belajar siswa pada masa pandemi di SMAN 1 Lembah Melintang dan SMAN 1 Lembah Gumanti. Angket kemandirian memuat 9 indikator, yaitu inisiatif dan motivasi belajar intrinsic, mendiagnosa kebutuhan belajar, menetapkan tujuan/target belajar, memilih, menetapkan strategi belajar, memonitor, mengatur, dan mengontrol belajar, memandang kesulitan sebagai tantangan, memanfaatkan dan mencari sumber yang relevan, mengevaluasi proses dan hasil belajar, self efficacy/konsep diri/kemampuan diri.

Kemandirian belajar siswa untuk indicator inisiatif dan motivasi belajar intrinsic, terlihat dari sikap belajar siswa dalam mengerjakan tugas matematika karena menyukainya, menunggu bantuan teman ketika mengalami kesulitan belajar matematika, dan menghindar mempelajari ulang materi matematika yang belum dikuasai. Pencapaian kemandirian pada indicator inisiatif dan motivasi belajar intrinsic di SMAN 1 Lembah Melintang adalah 69,17 berada pada kriteria kuat. Pencapaian kemandirian pada indicator inisiatif dan motivasi belajar intrinsic di SMAN 1 Lembah Gumanti adalah 72,04 berada pada kriteria kuat. Terlihat bahwa kemandirian untuk indicator inisiatif dan motivasi belajar intrinsic pada kedua sekolah menunjukkan kriteria yang sama, yaitu kriteria kuat.

Kemandirian belajar siswa untuk indicator mendiagnosa kebutuhan belajar terlihat dari sikap belajar siswa dalam mengetahui materi matematika yang perlu dipelajari ulang, merasa cemas mengetahui kekurangan sendiri dalam matematika, dan merasa terbebani memilih materi matematika yang perlu dipelajari. Pencapaian kemandirian pada indicator mendiagnosa kebutuhan belajar di SMAN 1 Lembah Melintang adalah 66,11 berada pada kriteria kuat. Pencapaian kemandirian pada indicator mendiagnosa kebutuhan belajar di SMAN 1 Lembah Gumanti adalah 73,12 berada pada kriteria kuat. Terlihat bahwa kemandirian untuk indicator mendiagnosa kebutuhan belajar pada kedua sekolah menunjukkan kriteria yang sama, yaitu kriteria kuat.

Kemandirian belajar siswa untuk menetapkan tujuan/target belajar, terlihat dari sikap belajar siswa dalam menetapkan target belajar matematika untuk membantu cara belajar, membuat jadwal belajar matematika untuk membantu mencapai target yang telah ditetapkan, dan merasa ringan belajar matematika tanpa target. Pencapaian kemandirian pada indicator menetapkan tujuan/target belajar di SMAN 1 Lembah Melintang adalah 74,44 berada pada kriteria kuat. Pencapaian kemandirian pada 
indicator menetapkan tujuan/target belajar di SMAN 1 Lembah Gumanti adalah 73,66 berada pada kriteria kuat. Terlihat bahwa kemandirian untuk indicator menetapkan tujuan/target belajar pada kedua sekolah menunjukkan kriteria yang sama, yaitu kriteria kuat.

Kemandirian belajar siswa untuk indikator memilih, menetapkan strategi belajar, terlihat dari sikap belajar siswa dalam mencoba menerapkan cara belajar teman yang pandai matematika dan menetapkan strategi belajar matematika tertentu akan menghambat kemampuan. Pencapaian kemandirian pada indicator Memilih, menetapkan strategi belajar di SMAN 1 Lembah Melintang adalah 73,33 berada pada kriteria kuat. Pencapaian kemandirian pada indicator Memilih, menetapkan strategi belajar di SMAN 1 Lembah Gumanti adalah 70,56 berada pada kriteria kuat. Terlihat bahwa kemandirian untuk indicator Memilih, menetapkan strategi belajar pada kedua sekolah menunjukkan kriteria yang sama, yaitu kriteria kuat.

Kemandirian belajar siswa untuk indikator memonitor, mengatur, dan mengontrol belajar, terlihat dari sikap belajar siswa seperti merasa cemas hasil belajar matematika dipantau, mengatur cara belajar matematika untuk membantu mencapai hasil yang baik, dan menilai pengaturan cara belajar matematika membatasi kerja kreatif. Pencapaian kemandirian pada indicator memonitor, mengatur, dan mengontrol belajar di SMAN 1 Lembah Melintang adalah 68.06 berada pada kriteria kuat. Pencapaian kemandirian pada indicator memonitor, mengatur, dan mengontrol belajar di SMAN 1 Lembah Gumanti adalah 69,09 berada pada kriteria kuat. Terlihat bahwa kemandirian untuk indicator memonitor, mengatur, dan mengontrol belajar pada kedua sekolah menunjukkan kriteria yang sama, yaitu kriteria kuat.

Kemandirian belajar siswa untuk indicator memandang kesulitan sebagai tantangan, terlihat dari sikap belajar siswa seperti menilai tugas matematika yang sulit menghambat pencapaian hasil belajar yang baik dan merasa tertantang mengerjakan soal matematika yang sulit. Pencapaian kemandirian pada indicator Memandang kesulitan sebagai tantangan di SMAN 1 Lembah Melintang adalah 68,75 berada pada kriteria kuat. Pencapaian kemandirian pada indicator Memandang kesulitan sebagai tantangan di SMAN 1 Lembah Gumanti adalah 67,34 berada pada kriteria kuat. Terlihat bahwa kemandirian untuk indicator Memandang kesulitan sebagai tantangan pada kedua sekolah menunjukkan kriteria yang sama, yaitu kriteria kuat.

Kemandirian belajar siswa untuk indikator memanfaatkan dan mencari sumber yang relevan, terlihat dari sikap belajar siswa seperti menilai mempelajari materi matematika yang sama dari beragam buku merepotkan, dan mempelajari beragam sumber untuk memperoleh pemahaman matematika yang baik. Pencapaian kemandirian pada indicator memanfaatkan dan mencari sumber yang relevan di SMAN 1 Lembah Melintang adalah 69,17 berada pada kriteria kuat. Pencapaian kemandirian pada indicator Memanfaatkan dan mencari sumber yang relevan di SMAN 1 Lembah Gumanti adalah 68,55 berada pada kriteria kuat. Terlihat bahwa kemandirian untuk indicator memanfaatkan dan mencari sumber yang relevan pada kedua sekolah menunjukkan kriteria yang sama, yaitu kriteria kuat. 
Kemandirian belajar siswa untuk indikator mengevaluasi proses dan hasil belajar, terlihat dari sikap belajar siswa seperti mengevaluasi sendiri hasil ulangan matematika sebagai umpan baik belajar, menganggap kegagalan dalam ulangan matematika yang lalu karena soal terlalu sulit, dan menyadari kesalahan pada ulangan matematika yang lalu. Pencapaian kemandirian pada indicator mengevaluasi proses dan hasil belajar di SMAN 1 Lembah Melintang adalah 74,17 berada pada kriteria kuat. Pencapaian kemandirian pada indicator mengevaluasi proses dan hasil belajar di SMAN 1 Lembah Gumanti adalah 75,00 berada pada kriteria kuat. Terlihat bahwa kemandirian untuk indicator mengevaluasi proses dan hasil belajar pada kedua sekolah menunjukkan kriteria yang sama, yaitu kriteria kuat.

Kemandirian belajar siswa untuk indicator Self Efficacy/konsep diri/kemampuan diri, terlihat dari sikap belajar siswa seperti merasa ragu dapat menyelesaikan tugas matematika yang sulit dengan baik, merasa yakin akan berhasil baik dalam ulangan matematika, tidak percaya diri untuk memberi pendapat pada saat pembelajaran jarak jauh bersama guru matematika, dan berpandangan tugas matematika yng berat adalah tantangan untuk berhasil dalam belajar. Pencapaian kemandirian pada indicator Self Efficacy/konsep diri/kemampuan diri di SMAN 1 Lembah Melintang adalah 67,29 berada pada kriteria kuat. Pencapaian kemandirian pada indicator Self Efficacy/konsep diri/kemampuan diri di SMAN 1 Lembah Gumanti adalah 67,54 berada pada kriteria kuat. Terlihat bahwa kemandirian untuk indicator Self Efficacy/konsep diri/kemampuan diri pada kedua sekolah menunjukkan kriteria yang sama, yaitu kriteria kuat.

Berdasarkan uraian di atas, siswa di SMAN 1 Lembah Melintang dan SMAN 1 Lembah Gumanti telah memiliki kemandirian yang kuat untuk berinisiatif dan motivasi belajar intrinsk, mendiagnosa kebutuhan belajar, menetapkan tujuan/target belajar, memilih, menetapkan strategi belajar, memonitor, mengatur, dan mengontrol belajar, memandang kesulitan sebagai tantangan, memanfaatkan dan mencari sumber yang relevan, mengevaluasi proses dan hasil belajar, self efficacy/konsep diri/kemampuan diri.

\section{KESIMPULAN}

Berdasarkan perolehan skor angket kemandirian belajar siswa di SMAN 1 Lembah Melintang dan SMAN 1 Lembah Gumanti diketahui bahwa skor angket berada pada kriteria yang sama, yaitu kriteria kuat. Jadi dapat disimpulkan bahwa tidak terdapat perbedaan antara kemandirian belajar siswa di SMAN 1 Lembah Melintang dan SMAN 1 Lembah Gumanti pada masa pandemic.

\section{DAFTAR PUSTAKA}

A Saefullah, P Siahaan, I. M. S. (2013). Hubungan Antara Sikap Kemandirian Belajar Dan Prestasi Belajar Siswa Kelas X Pada Pembelajaran Fisika Berbasis Portofolio. WaPFi (Wahana Pendidikan Fisika), 1(1), 26-36. https://doi.org/10.17509/wapfi.v1i1.4891

Ali Sadikin, A. H. (2019). Pembelajaran Fiqh Mu'Āmalāt Berorientasi Literasi Finansial. TARBAWY : 
Indonesian Journal of Islamic Education, 6(2), 187-192. https://doi.org/10.17509/t.v6i2.20887

Amalia, A., Syafitri, L. F., Sari, V. T. A., \& Rohaeti, E. E. (2018). Hubungan Antara Kemampuan Pemecahan Masalah Matematik dengan Self Efficacy dan Kemandirian Belajar Siswa SMP. 1(5), 887-894.

Ansori, Y., \& Herdiman, I. (2019). Pengaruh Kemandirian Belajar terhadap Kemampuan Pemecahan Masalah Matematis Siswa SMP. Journal of Medives : Journal of Mathematics Education IKIP Veteran Semarang, 3(1), 11. https://doi.org/10.31331/medivesveteran.v3i1.646

Asep Sukenda Egok. (2016). Kemampuan Berpikir Kritis dan Kemandirian Belajar dengan Hasil Belajar Matematika. Journal of Chemical Information and Modeling, 53(9), 1689-1699. https://doi.org/10.1017/CBO9781107415324.004

Asmar, A., \& Delyana, H. (2020). Hubungan Kemandirian Belajar Terhadap Kemampuan Berpikir Kritis Melalui Penggunaan Software Geogebra. AKSIOMA: Jurnal Program Studi Pendidikan Matematika, 9(2), 221-230. https://doi.org/10.24127/ajpm.v9i2.2758

Assagaf, G., \& Ambon, K. (2017). the Influence of Independent Learning and Self. JURNAL DAYA MATEMATIS, 5(2), 117-123.

Ayu Kustiani R, Dewi Novianti, Dhani Fitri Yanthi, I. A. (2007). Pengujian hipotesis dua sampel. In Jurusan Matematika FMIPA Unsyiah, April 2007 (Edisi Revisi) (Vol. 2007, Issue April).

Darma, Y., Firdaus, M., \& Haryadi, H. (2016). Hubungan Kemandirian Belajar Terhadap Kemampuan Pemecahan Masalah Matematis Mahasiswa Calon Guru Matematika. Edukasi, 14, 169.

Ermayeni, S., Jufri, L. H., \& Melisa, M. (2020). Effect of The Application of The Problem Based Learning Model to The Mathematical Problem Solving Ability. Eduma: Mathematics Education Learning and Teaching, 9(1), 74. https://doi.org/10.24235/eduma.v9i1.5660

Karlimah, WS, R., Pranata, O. H., \& Lidinillah, D. A. M. (2012). Pengembangan Kemampuan Proses Matematika Siswa Melalui Pembelajaran Matematika dengan Pendekatan Tidak Langsung di Sekolah Dasar. Jurnal Pendidikan MIPA, 13, 105.

Latif, S., \& Akib, I. (2016). Mathematical Connection Ability in Solving Mathematics Problem Based on Initial Abilities of Students At Smpn 10 Bulukumba. Jurnal Daya Matematis, 4(2), 207. https://doi.org/10.26858/jds.v4i2.2899

Mayasari, T. R. (2019). Pengaruh Kemandirian Belajar terhadap Kemampuan Pemecahan Masalah Matematis Siswa SMP. Jurnal Cendekia: Jurnal Pendidikan Matematika, 3(1), 82-88. https://doi.org/10.31331/medivesveteran.v3i1.646

Mulyono, D. (2017). The influence of learning model and learning independence on mathematics learning outcomes by controlling students ' early ability. International Electronic Journal of Mathematics Education, 12(3), 689-708.

Nurhayati, E. (2017). Penerapan Scaffolding untuk Pencapaian Kemandirian Belajar Siswa. Jurnal Penelitian Pendidikan Dan Pengajaran Matematika, 3(1), 21-26. http://jurnal.unsil.ac.id/index.php/jp3m/article/view/Eli31

Prisha Bahri, S., Zaenuri, \& Sukestiyarno, Y. (2018). Problem Solving Ability on Independent Learning and Problem Based Learning with Based Modules Ethnomatematics Nuance. Unnes Journal of Mathematics Education Research, 7(2), 218-224. http://journal.unnes.ac.id/sju/index.php/ujmer

Risnanosanti. (2013). Kemandirian Belajar dan Kemampuan Pemecahan Masalah Matematis 
Mahasiswa Program Studi Pendidikan Matematika. Prosiding, 978-979.

Wulandari, S. P. (2016). Menciptakan Kemandirian Belajar Siswa Melalui Pembelajaran Berbasis Discovery Learning dengan Assessment for Learning. PRISMA, Prosiding Seminar Nasional Matematika, 226-232. https://journal.unnes.ac.id/sju/index.php/prisma/article/view/21475\%0Ahttps://journal.unnes.ac.i d/sju/index.php/prisma/article/download/21475/10159 